\title{
The Impact of Holodomor Studies on the Understanding of the USSR
}

\author{
Andrea Graziosi \\ University of Naples Federico II
}

\begin{abstract}
This paper investigates what the Holodomor tells us about the development and dynamics of Soviet history. It starts by examining the evolving relations between Stalin and the peasantry during the Soviet Union's first decades as well as the social, economic, moral, and psychological consequences in the USSR after 1933 following the destruction of traditional rural society. The relationship between the Holodomor and the viability of the Soviet system will then be discussed along with the opportunities that history presented to the Soviet leadership after 1945 to reverse the country's critical 1928-29 decisions. This leadership's awareness of the tragedies of the 1930s in the countryside, as well as of their consequences, will then be raised, before shifting the focus to the linkage between the peasant and the national questions in Soviet history. In this context the Holodomor will be discussed as a tool to solve both the peasant and the national "irritants" caused by Ukraine to both the Soviet system and Stalin's personal power. The legacy of such a "solution" will then be addressed, including a consideration to the background of the collapse of the Soviet system from the perspective of the sustainability of a state whose past is marred by unacknowledged genocidal practices. Finally, the consequences of the growing awareness of the Holodomor's importance and nature on the USSR's image will be discussed. In particular, the question of the "modernity" of the Soviet system and of the "modernizing" effects of Stalin's 1928-29 policies will be raised.
\end{abstract}

Keywords: Holodomor, USSR, genocide, Stalinism, peasantry, national question

$\mathbf{T}$

his paper assesses the impact of the Holodomor on our understanding of Soviet history and reflects upon what the famine and its legacy tell us about the development and dynamics of this history, which obviously includes that of Ukraine. It begins with a discussion of how that history appears if one assigns the Holodomor-along with collectivization and the civil war-a proper role. From this perspective, the evolving relations between Stalin and his regime with the peasantry prove crucial to the understanding of the Soviet Union's first decades.

Several issues will be addressed. The viability of the Soviet system in relation to the collective system the famine forced upon the country; and the opportunities that history presented to the Soviet leadership after the Second World War victory-and then again after Stalin's death-to change 
the 1928-29 decisions regarding collectivization (this will be done in light of Deng Xiaoping's 's reforms in China). I will discuss the Soviet ruling elite's awareness of, and attitudes toward, the tragedies of the 1930s in the countryside, as well as of their consequences. The weight of the illusions regarding the potential of collectivized agriculture and of the taboo Stalin successfully imposed upon the famines will be analyzed in connection with the structural limits of the post-1953 reforms and the economic and social degradation of a system they were fundamentally unable to change.

I shall deal with the close linkage between the peasant and the national questions in Soviet history, of which Ukraine was the paramount case, especially in Stalin's reckoning. In this context, the Holodomor will be discussed as a tool that solved, in one stroke, both the peasant and the national "irritants" to the Soviet system and Stalin's personal power, given Ukraine's relative autonomy. The legacy of such a solution-for example, in the realm of language and culture-will be addressed. I will, in short, return to the question of the collapse of the Soviet system from yet another perspective, i.e., that of the viability of a state and system whose past is marred by an unacknowledged genocide, possibly more than one. Finally, I will turn to the consequences that the growing awareness of the importance and nature of the Holodomor have had on the USSR's image and its representation by historians. In particular, the "modernity" of the Soviet system and of the "modernizing" effects of Stalin's 1928-29 policies will be raised.

This paper is based on my personal experience as a historian of the USSR and my participation in the extraordinary period of research into Soviet history in the wake of the collapse of the Soviet Union in 1991. In 1986-87 my examination of Italian diplomatic dispatches forced me to confront the Holodomor. They made for painful reading, but I was immediately aware that my understanding of Soviet history and of the twentieth century in Europe was going to be radically altered. The impact of these reports was furthered by the admittedly partial but substantial opening of Soviet archives and by the documents emerging from them. Among them, the most notably were:

a. The Cheka/OGPU operational summaries (svodki) on state-peasant relations during the civil war; ${ }^{1}$

\footnotetext{
${ }^{1}$ I was given the reports to prepare an introduction to the first volume (1918-1922) of the series Sovetskaia derevnia glazami VChK-OGPU-NKVD, 1918-1939. However, the editor, V. P. Danilov, refused to publish my text because-by extending to the Soviet period a concept he had developed for the late Tsarist period-it spoke of a war against the peasantry as a key to the understanding of Soviet history, and thus was too "anti-Soviet." The materials he kept publishing eventually convinced him to
} 
b. Materials on the 1930 revolts by Ukrainian villages against dekulakization and collectivization that I found in the Ordzhonikidze secret archive and the OGPU svodki on the 1930-33 countryside;

c. The large body of documentation, testimonies and scholarship on the Holodomor and the 1931-34 famines-but also on the 1920-22 and the 1946-47 ones - that became increasingly available after the collapse of the USSR; and

d. The documents selected the multi-volume series Dokumenty sovetskoi istorii, which started to appear in Moscow in 1993 under the supervision of Oleg Khlevniuk and myself.

In dealing with these questions, I could not but rely on my previous writings. Readers will find there a more detailed treatment of events and problems that are often summarized here in an effort to examine the Holodomor's impact on Soviet history and our understanding of it. ${ }^{2}$

\section{The Peasant Question in Soviet History}

The Holodomor-and other famines that accompanied and followed it, beginning with the civil war and continuing through Stalin's deathhighlight the opposition to the new state by different "peasantries," which I refer to as the Great Soviet Peasant War of 1918-1934. This is a fundamental key to understanding the history of the USSR's first decades.

This acknowledgement has a devastating impact on more traditional interpretations: the "workerist" rhetoric-in all of its variants, both proand anti-regime ${ }^{3}$-appears, precisely, only as rhetoric with little relevance for the dynamics of Soviet history. Various "modernization" theories and

espouse a similar view, which I had meanwhile formalized in Graziosi, Great Soviet Peasant War.

2 The reader is referred, in particular, to: "The Great Famine of 1932-33"; "Vneshniaia i vnutrennaia politika Stalina"; "Stalin, krest'ianstvo i gosudarstvennyi socializm;"; L'Urss di Lenin e Stalin; L'Urss dal trionfo al degrado (an abridged edition of the two volumes has been published in France by the Presses Universitaires de France in 2010 and is also forthcoming from Rosspen in Moscow); and "Stalin's Genocides, and...?".

3 The former go from the early Stalinist presentation of Soviet history as a heroic process, led by a workers' party, of building a worker state, to later readings that, while not denying the great suffering of the 1930s, presented them as necessary for the construction of socialism. The latter was initially supported by former oppositionists, who presented the Stalinist state as a perversion of the "true" worker state. It was revived after 1991 by the archival findings about the intense repression the regime carried out in factories already during the civil war and later, especially after 1927. 
interpretations that construct a particularly Soviet "welfare state" do not fare any better. If we look backward from 1931 to 1934 , we see the following:

a. From the spring of 1918 onward and through de-kulakization, collectivization and the famines, "classes" had but a marginal (although certainly not a non-existent) role in what basically was an original, ideologically inspired, very violent and primitive statebuilding attempt. In this process, individual leaders (and their psychologies and mentalities), state and Party bureaucracies, and even common criminals played crucial roles ${ }^{4}$;

b. Peasant opposition to this kind of state-building and the peasants' role in supporting national liberation movements, as in 1919 Ukraine, were also crucial in the affirmation of those indigenization policies (korenizatsiia) that represented one of the Soviet Union's most important and original features. Their fate-most notably but not exclusively in Ukraine-was to be determined by developments in the state-peasantry confrontation in the early 1930s;

c. The previous two points are confirmed by the substantial and impressive geographical, ideological, and even personal and "family" continuity between the peasant-based social and national revolts of 1918-20 and those against de-kulakization, requisitions, and collectivization in 1930-31. Remarks by Vsevolod Balyts'kyi in 1930 and Kliment Voroshilov in 1934 prove that Soviet leaders were keenly aware of this continuity, which was strongest in territories where famine reached its harshest peaks in 1931-34, particularly the regions laying between Kyiv and Kharkiv (the data collected by the HURI Holodomor Atlas Project are in this regard quite impressive) as well as the Kuban, the Don and Volga regions, and Central Asia.

If we now try instead to look from 1933 forward, thus entering less thoroughly studied territories, we can observe this:

a. The powerful impact that the famine experience-which included harrowing personal suffering, extreme survival strategies (even cannibalism), and devastating mourning-had on peasants' behaviours, psychologies, mentalities, and even religion. About ten years ago, I raised the question of what was the legacy for the

\footnotetext{
4 The criminal element was very relevant in the formation of the most violent of those very bureaucracies, a fact that the Cheka/GPU reports repeatedly note and that is now also being stressed by students of other great state-led twentiethcentury transformative projects.
} 
population of those several months in which millions died; what was the impact of depression, which struck rural families that could not mourn their dead and were deprived of religious and other authorities who might have help them cope with their grief (Graziosi, "Great Famine" 157-60). Unfortunately, we lack a social history "from-below" of the famine, as lived and seen by peasantsthis being in my judgment the new frontier for Holodomor studies. But we do have torturing glimpses of it in numerous eyewitness accounts, in the trials for cannibalism, and in GPU documents, which raise most gripping questions about individual and collective behaviours, as well as beliefs inspired by collectivization and hunger. ${ }^{5}$

b. The increased role alcohol played as a consequence of both the peasants' and the state's behaviour. Relying on old habits that the civil war and the 1921-22 famine had strengthened, peasants in the 1930s increased the use of alcohol to escape extreme hardships, depression, and everyday misery. Meanwhile the Soviet statelooking for money-made sure that alcohol was available in increasing quantities and without competition in country stores. We know that already in the mid-1920s Stalin had justified the increase in the production and sale of vodka as a way to find the funds needed for industrialization. The crisis provoked by the "great offensive" he launched in 1929 made things even worse. On 1 September 1930, while official rhetoric was busy extolling the new "Soviet man," Stalin wrote to Molotov, "I think vodka production should be expanded (to the extent possible). We need to get rid of a false sense of shame and directly and openly expand as much as possible the production of vodka for the sake of the real

\footnotetext{
5 For instance, a GPU report from Vinnytsia, dated January 1934, deals with the illegal religious services held for the famine's victims, which multiplied in previous months, and were accompanied by rumours about miracles. "Two strangers carrying icons" had entered a village "saying that in a nearby hamlet a person claiming to have been resuscitated from death by starvation urged believers, and women who had not joined collective farms in particular, to organize wakes to remember the famine's victims. If such wakes were organized, God would have forgiven the people's sins. Otherwise an even worse famine would have come, which nobody would have survived." According to the report, hundreds of people, including different kinds of formerly repressed people (such as previously deported peasants), joined such gatherings, which sent delegations to surrounding villages. "Operational detachments were however dispatched to the infected districts, and orders were given to all OGPU organs in order to stop the phenomenon." See Werth and Berelowitch 554 .
} 
and serious defense of our country" (Lih et al 209; Khlevniuk 209). Soviet vodka production thus surpassed for the first time that of the much larger Tsarist empire, and vodka came to represent up to forty percent of the rural stores' total sales and to provide approximately twenty percent of state revenues (Hessler 164; Graziosi, L'URSS di Lenin e Stalin 300ff). The new regime thus became a pusher of narcotics to an alien and destitute population, and also in this way caused the ruin of traditional peasant, and human culture.

c. What Sergei Maksudov rightly calls dehumanization (raschelovechivanie), that is, the "change in the moral and ethical consciousness of the Soviet citizens as a result of the collectivization and famine." 6 This transformation became an important dimension of what Prof. Krasil'nikov has termed Stalin's repressive de-peasantization (repressivnoe raskrest'ianivanie). Among other things, these phenomena caused the appearanceespecially in the countryside-of a "new human being" who "was passive, meekly carried out even the most absurd instructions of the authorities, was ready to work for the lowest wage or even for free, did not like and did not respect his own work, lacked confidence, feared the unexpected, if he could, did not obey laws, considered theft the natural form of the redistribution of property, and did not feel self-respect" (Krasil'nikov 44-55). ${ }^{7}$

In the long run these processes left a legacy represented by the terrible social and psychological conditions of rural Soviet settlements, whose "death" the "village writers" (derevenshchiki) started to describe in their novels already at the beginning of the 1950s (Valentin Ovechkin's Raionnye budni being one of the best examples). Above all, they contributed to the peculiar dynamics of Soviet demographic evolution. As Meslé and Vallin among others have demonstrated, alcoholism and psychological deprivation had an impact on life expectancy-that of men in particular (Meslé and Vallin). The Soviet leaders' awareness of its dramatic effects was to play an important role in igniting the reform efforts of the 1980s, thereby accelerating the demise of the Soviet system.

\footnotetext{
6 The description of "dehumanization" is found in the sub-title to Maksudov.

7 Needless to say, not everybody possessed such features, and those who did, possessed them in varying degrees.
} 


\section{The Holodomor And the Viability of the Soviet System}

The Holodomor casts its shadow on yet another of the major questions pertaining to the viability of the Soviet system, namely its agricultural policy. Stalin forced collectivization down the throat of peasants by a Pavlovian use of hunger; the peasants immediately recognized it as a "second serfdom." According to Anatoly Chernyaev, in the 1980s even the General Secretary of the Party-unaware of the GPU reports that recorded such opinions from 50 or so years earlier- "scornfully" called the collective farms (kolkhozy or kolhospy) an "unshakable" servile system run by "kolkhoz generals" (Chernyaev 216). But by making it possible to impose a new kind of serfdom on the countryside, the Holodomor and the Soviet famines also established the structural foundations of the agricultural crisis that has marked Soviet history since Stalin's "revolution from above." By the 1970s it had reached unsustainable proportions.

This crisis was the direct consequence of the system that emerged from the peasants' defeat, and from that of "peasant" nations, of which Ukraine was in Stalin's eyes by far the most important. Once hunger ensured such defeats and the stabilization of the collective farm system, Stalin was forced to introduce two measures that temporarily saved what remained of peasants and peasant culture, yet at the same time profoundly deformed them. The end of rationing and the introduction of the "kolkhozian market," which allowed peasants to shop and sell in cities, were a major relief for the villages (Davies and Khlevniuk 87-108). But the most important measure was the right granted to kolkhozniki in 1935 to cultivate a small personal plot (0.2-0.5 hectare), the so-called lichnoe podsobnoe khoziaistvo (LPKh). Kolkhozniki could thus continue to be mini-muzhiki on the side (Lewin 18687) and the terrible de-peasantization of the early part of the decade ended up by generating a system that preserved at its core a mini-peasant who was fated to slowly fade away in subsequent years, after providing the country with new flesh and blood during the war and the post-war "modernization."

Together with the establishment of the collective farm system, these two measures defined the new rural economic system. Initially, this meant the ability to buy and sell, as well as exploit plots, which improved the conditions of the collective-farm workers. Yet, even though this ameliorated the previous situation (not a difficult task, given the misery that had prevailed in the countryside since 1928), the new system also pulled in opposite directions. As attested to by his speech at the March 1935 kolkhoz conference (Pravda 15 March 1935), Stalin was perfectly aware of the situation: 
If in your artels you don't yet have food in abundance and can't give to the collective farmer and his family everything that they need, the kolkhoz can't take it upon itself to satisfy both public and private needs. In that case it would be better to say directly that this sphere is public, and that one is private. It would be better to admit frankly, openly and honestly, that a collective farm household should have a private plot, not a big one, but private. It's better to proceed from the fact that there is an artel, public, large, social, and decisive, necessary to meet public needs, and there is alongside it a small, private farm, necessary to meet the needs of the collective farmer. As long as there is family, children, private needs and private tastes, you can't fail to pay attention to them. And you don't have the right to ignore the personal interests of collective farmers. Without this, the consolidation of the kolkhoz is impossible.

The divergent interests regulating these two spheres of endeavor doomed them both to atrophy. The "big, social, decisive" sector generated a lack of interest by collective-farm labourers in working for it, since everybody knew, and official proclamations openly stated, that its production belonged to the state. The waning of the LPKhs was predetermined by its miniscule dimensions and by the vigilance exerted by the state to prevent it from growing (and to limit its productivity) in the fear that the mini-muzhik would devote most of his time to his plot.

The state was thus adamantly opposed to the development of the private sector, and the collective farmers were poised against that of the social one. A letter that the peasants of an Ural collective farm mailed in 1938 to local authorities clearly stated:

Collective farms... function first and foremost as agents of politicaleconomic campaigns. Their administrations operate-even if not always satisfactorily-as tools of superior organizations entrusted with fulfillment of plans of food procurement for the state and other tasks set by the plan. Collective farms as of now do not perform well enough to convince the population that their purpose is to raise the standard of living of collective farmers.... The conditions of collective farms... appear as if designed to instill in the population the idea that it would be better to return to capitalism. Such conditions could be produced by the enemies of the people. (Graziosi, L'Urss di Lenin e Stalin 394 ff.; see also Beznin and Dimoni; Beznin, Dimoni and Iziumova; Kessler and Kornilov; Popov)

Not surprisingly, as we can read in yet another document, already by 1939, "most collective farm workers... turn their private plot into their main concern, and the kolkhoz fields into subsidiary activities, and evade participation in social work" (Kessler and Kornilov 111-15). The state considered such behaviour a crime, and it was punished as such. Peasants reacted by devising all sorts of schemes, including pilfering (which hunger 
had made an everyday necessity), to assure survival (Fitzpatrick 57, 65-67, 72-73). This amounted to the destruction of the previous peasant way of life (byt), whose moral and economic pillars had already started to disintegrate under the impact of de-kulakization, collectivization and hunger, growing alcohol consumption, and the ban on religion.

Even though potentially capable of guaranteeing both the survival of the peasantry and the transfer to the state of the main bulk of agricultural production, the 1935 "compromise" that the state was able to enforce (following its victory through hunger) provided Soviet agriculture and Soviet society in general with a fragile basis for food procurement. It was to remain one of the system's weakest points until its final collapse, to which it certainly contributed.

The difficulty of the transition to a Communist future were summed up in Stalin's Ekonomicheskie problemy sotsializma v SSSR (Economic Problems of Socialism in the USSR, 1952), showing that he too realized that the agricultural system that emerged from the 1929-33 catastrophe was in a quagmire. Significantly, he attributed the problem to the collective farms, whose very existence precluded the abolition of the "law of value." This was so because kolkhozy were cooperatives owned by peasants, who could accept only the exchange of goods as the basis of their economic relationships with the socialist cities. Money was thus needed to regulate these exchanges, and communism could only come about when the two Soviet forms of property, the state and the cooperative, would merge into one single, moneyless national economic unit.

However, nothing prevented the state from "socializing" the collective farms as well, and thus from building such a unitary system. Yet Stalin did not want to do it, possibly because War Communism and the 1929-30 crisis had taught him that without money the Soviet system could not survive even in the short term. He thus found justifications not to act (e.g., kolkhoz property was socialist property, and it was therefore impossible to deal with it as with capitalistic property), and reacted angrily to proposals to speed up the Communist transformation of the countryside, such as those advanced by Khrushchev in early 1951.

The Communist future thus became a mirage, and Stalin sensed there was no road leading to it. His solution was to reaffirm the validity of Marx's tenets, while at the same time proposing the postponement of the transition to communism by introducing yet new "stages" between the socialist and the Communist ones, deferring the achievement of the latter to an ever remote future. The Soviet Union, Stalin explained, had entered the stage of the preparation of the transition to communism, which meant building the "preliminary conditions for it": the old duo, "proletarian dictatorship- 
communism," became a trio in 1936 with the insertion of socialism (Graziosi, L'Urss $126 \mathrm{ff}$.) and was later expanded into a quartet. ${ }^{8}$

The fragile equilibrium of the mid-1930s started to break up due to the pressure the state imposed upon the countryside in order to prepare for war, and then, and even more, to face the war's initial, terrible defeats. Threatened by Moscow, kolkhoz directors only thought about extracting the highest possible quantity of foodstuffs from their domains; at the same time goods disappeared from rural stores, and the police disbanded the queues of peasants that formed before city ones. Before the war started, those who had not been able to flee the kolkhozy were often spending 70 percent of their time in the collective fields, often for little to no compensation (Graziosi, L'Urss di Lenin 463 ff.).

Between 1941 and 1945 starvation and suffering were universal and death frequent. Nevertheless, crops yields, which were often lower than during the early 1930s, did not result in new mass famines. Kolkhozniki owed their survival to their private plots and to their cows. Yet the war and the pressure the state exerted upon the countryside struck another mortal blow to Soviet villages: after 1945, generally, only invalids returned to them, strengthening the trend toward the aging and the feminization of their residents.

Above all, the war did not fully integrate peasants into the "Soviet narod." In the parts of the country that remained under Soviet control, it could have happen, and there certainly were steps in this direction. Stalin spoke to "brothers and sisters," Russian Orthodox churches were reopened and a patriarch re-elected, official propaganda rediscovered "national" traditions (and not only Russian ones) - and suffering could be justified by the need to vanquish foreign invaders.

Yet, one must always remember that for some national groups the war meant a definite exclusion from that very narod, an exclusion for which they paid dearly (Polian). Ukraine came to occupy a sort of middle ground: its Western regions were considered de facto enemy territory, while its larger "Soviet" part was tarred by the undeserved sentence of "betrayal." This was seldom officially proclaimed, but was in fact generally understood, although it should always be remembered that in 1941 the Soviet Ukrainian Front was the one that resisted longest and most valiantly. Above all, and more generally, once victory was achieved the "pact" the villages thought to have signed with the Soviet state did not materialize. NKVD-MVD reports from different regions tell us in detail, and with impressive uniformity, what the peasants were hoping for:

\footnotetext{
${ }^{8}$ Brezhnev later added one more stage to this scheme, "developed socialism."
} 
Evdokiia Mikhailovna Bazhenova, from a kulak family (Rybnoe village) states: "very soon collective farms will be disbanded, I just can't wait for it." Andrei Grigor'evich Samokhvalov, tractor brigadier from the Shumikhinskaya MTS, tells other tractor drivers: "collective farms did not live up to expectations - that is why it was decided to get rid of them"... Citizen Mariia Ignat'evna Mironova... declares that "England and America proposed that our government accept five conditions: to reintroduce epaulettes in the army, to open churches, to disband collective farms, to release all prisoners and to send all the Jews to the front"... Citizen Agniia Filippovna Ozhgibesova declares: "everybody is talking about it, soon there won't be collective farms anymore, churches will be reopened, and life will be good."... Collective farmer Anna Grigor'evna Porosenkova declares: "America gave Stalin three orders: reintroduce epaulettes in the army, open churches and disband collective farms, then the war will end... we shall live as individual farmers. ("Iz ob"iasnitel'noi zapiski" 425-27) 9

The post-war years brought instead a new famine (Zima), more work days (trudodni) in the collective farm fields, more work obligations (trudpovinnosti) of different sorts, more taxes in kind and money on the LPKh, and more repression, especially after the passing of the cruel 1947 laws for the punishment of theft of private and state property, which ruined millions of lives and helped produce a new generation of people living a marginal existence (marginaly) (Krasil'nikov and Shadt; Kozlov; Zubkova and Zhukova). As General Vasilii Rybal'chenko told his colleague Fillip Gordov in December 1946, "We have adopted such a policy that nobody wants to work anymore. It must be openly said that all the kolkhozniki hate Stalin and wait for his death... They think that if Stalin dies, the kolkhozy will die too..." (Zubkova 155-56). Hundreds of interviews, gathered after the war by the Harvard Refugee Interview Project, fully confirm the point: hatred for Stalin and Communist leaders was higher among kolkhozniki than in any other social group. ${ }^{10}$

Meanwhile, the increase of the economic and repressive pressure on both the kolkhozy and the LPKh was transforming the late Stalin countryside into a somber, darker replica of Mikhail Saltykov-Shchedrin's

\footnotetext{
9 Two years later, in 1945, peasants from different regions maintained, "during the San Francisco conference [establishing the United Nations], it was proposed to Molotov that the collective farms be disbanded, churches opened and free trade allowed."... In a number of kolkhozy... they say: "A special commission on dissolution of collective farms has been created in Moscow." Members of kolkhoz "Iskra" (in the Pskov region) ... asked one district worker: "How soon will collective farms be disbanded? If it was not for collective farms, we would live better and would bring more benefits to the state (Livshin and Orlov 77-79).

10 The rich Project materials are available at http://hcl.harvard.edu/collections/ hpsss/about.html. Inkeles and Bauer provide a summation of the Project.
} 
Poshekhonskaia starina. A self-pretending "modernity" had generated a quasi-servile system that was in many respects even harsher than, and of course quite different from, the ancien régime. After 25 years of pitiless exploitation, the Soviet countryside lay in ruin. Not surprisingly, when in the 1990s researchers tried to collect the memories of the few surviving witnesses of the early 1930s famines, they met with peasants almost unable to make a distinction among the different parts of the 1929-1953 period. The whole era had solidified in their minds as one of state violence and intense suffering, of hunger and deprivation, thus making it difficult to use their testimonies. ${ }^{11}$

\section{Soviet Leaders And the Peasant TRAgEdy}

In spite of official pronouncements to the contrary, including their own, Stalin's top aides were fully aware of the USSR's agricultural disaster (Khlevniuk and Gorlizki 26-27, 186). This was clearly indicated by the measures they took to remedy the situation and to improve the collective farmers' lot soon after the leader's death. One could therefore maintain that the most significant periods of Soviet reformism (1953-56) started as a reaction to the catastrophe that the years 1929-33 had brought about in the countryside. ${ }^{12}$

What, then, was the post-Stalinist Soviet elite's relationship to, and awareness of, the peasants' misfortunes, the Holodomor and the other famines of 1931-34? That elite's first generation had first-hand knowledge of these tragedies, which was refreshed by the 1946-47 famine, as it is evident from the pages Khrushchev devotes to it in his memoirs (Khrushchev 9-17, 310-12). This knowledge, as well as the "common feeling" born out of the war and of victory, made Beriia, Khrushchev, Malenkov and the Soviet top leadership not insensible to the plight of Ukraine and the collective farmers and created the atmosphere in which some pro-peasant measures were adopted in 1953-56.

Khrushchev's knowledge of Ukraine's repeated tragedies and the guilty feelings this knowledge generated are also evident in his ideas of a Ukraine so much victimized as to deserve special compensation. On 20 June 1944,

\footnotetext{
11 This was also my experience when I briefly worked as a consultant for Serhiy Bukovsky's movie Zhyvi / The Living, which is based on some magnificent interviews. Albeit indirectly, Frank Sysyn raised a similar point in his "Ukrainian Famine," regarding the activities of the Ukrainian diaspora.

12 This was not only a Soviet phenomenon: the Hungarian leader Imre Nagy directed a Siberian kolkhoz in the 1930s, and as a child Czechoslovakian leader Alexander Dubček personally and deeply experienced the 1931-33 Kazakh horror.
} 
for instance, he wrote Stalin suggesting to expand the Ukrainian territory westward to include what he deemed ethnically Russian and Ukrainian lands, Chełm (Ukrainian: Kholm) included. And a few months later he spoke for the first time of giving Crimea to Ukraine, from whence the Tatars had just been deported and therefore required resettlement: "Ukraine is in ruin, but everybody wants something from it. And what if we gave the Crimea to her, no strings attached?"13 The poisonous "gift" of Crimea in 1954 thus might in some way be linked to the awareness that Ukraine had to be somehow "repaid."14 Brezhnev, too, who lived the first part of his life as a "Ukrainian," only to become a "Russian" later, had personal experience of the 1930s and shared similar feelings. Though he continued to vigorously enforce the famine taboo, he introduced in 1964-65 an minimal pension plan for kolkhozniki and in 1974 he granted them the right to obtain internal passports, thus ending the most evident stigma of social inferiority that 1932-33 had been imposed upon the countryside.

At the republican level, Ukrainian Party leader Petro Shelest, who had lived through collectivization and famine, went as far as to try to break the Holodomor taboo (Kul'chyts'ky 431-49). In 1967, after the first serious works on collectivization were written, if not published, he demanded that the Party academic collective charged with writing a new history of socialist Ukraine add a paragraph on the 1932-33 famine to the chapter on collectivization. The group's members, quite embarrassed, did not dare do so, and Moscow's subsequent negative reactions to the idea proved their self-censorship prescient in its own way.

The taboo thus remained in force, and was even reinforced in the $1970 \mathrm{~s}$ and 1980s, in large measure as a reaction to advances in the knowledge of the Holodomor, owing to the efforts of the Ukrainian diaspora. One may surmise that the new generation of Soviet leaders that came to power in the 1980s simply was unaware of the reality of the 1930s famines because of that taboo and their younger age, and thus, the lack of a direct experience of earlier events. It follows that because of this, they were more open to discuss the matter as an issue that some really believed was "distorted" by "capitalist propaganda." In a way, therefore, naïveté was a component (one among many) of what was to be famously termed glasnost.

\footnotetext{
13 Knyshevskii, P. “Strikhi k portretu kremlevskoi galerei." Novoe vremia 9 (1993). Cited in Shapoval, 29.

14 All the same, the reality of more effective administration of this economically depressed peninsula was the far more pertinent consideration in its transfer to the jurisdiction of the Ukrainian SSR. Sasse, Chapter Five, "Reassessing the 1954 Transfer of Crimea" 107-26.
} 
The breaking of the Holodomor taboo was hastened by the spread of glasnost after the 1986 Chornobyl accident. Only 20 months later, at the end of 1987, Volodymyr Shcherbyts'kyi officially acknowledged the existence of the 1932-33 Ukrainian famine. The process was perhaps also accelerated by the re-emergence of long-forgotten personal recollections among new leaders. As their own memoirs tell us, Gorbachev had lost three uncles to the famine in North Caucasus, and Yeltsin's family had been dekulakized and deported: how could they have been indifferent to new stories about collectivization and hunger coming to the fore (Gorbachev; Yeltsin; Colton)?

This brings us again to the place that the Holodomor and the other famines of the early 1930s must be assigned in understanding the collapse of the USSR. The unquestionable early success of the 1953-56 agricultural reforms-which substantially increased the collective farm workers' and the country's standard of living, thereby partially altering the 1929-33 legacy-failed to spark a self-sustained development. This failure, and the subsequent agricultural crisis provide us with yet another, and interesting viewpoint on this crucial event.

Those reforms represented a unique opportunity to reform the Soviet system and thus to secure its survival. Khrushchev-and Beriia and Malenkov before him-did much and found the courage to denounce Stalin, an unpopular move among Party cadres. But this left the essential structure of Stalin's system (quite unpopular among the kolkhozniki) substantially intact at a time in which the Soviet countryside still retained a certain amount of energy, and rural residents still represented more than 50 percent of the country's inhabitants. Khrushchev did this because he was personally convinced that the collectivized system built upon the great famines was indeed a superior one. In fact, in his "secret speech" he attacked Stalin for his cruelty, the great trials, and the Terror of the late 1930s as well as for the war's initial misfortunes, but passed very positive judgment upon his pre-1934 policies.

Only 20 years later, in 1976, China's Deng Xiaoping grappled with the legacy of the colossal famine caused by the Great Leap Forward (current estimates speak of 30 to 40 million victims). He had contributed to its unleashing, but had quickly realized it was a tragic mistake. Relying on the policies devised in the first half of the 1960s to remedy that tragedy before Mao initiated the catastrophic "Cultural Revolution," Deng dismantled Mao's system, but preserved Mao's cult of personality in spite of his awareness of the man's responsibilities and crimes, which had personally 
affected him and his family. ${ }^{15}$ Deng thus reversed the terms of Khrushchev's equation, and did it because he was convinced that the socialist economic system was doomed, especially in the countryside, and wanted to save the Chinese state and political system.

The initial success of the Soviet reforms during the 1950s and their subsequent failure are thus linked to Khrushchev's and the Soviet elite's (with the possible exception of Beriia) limited mental horizons, which were largely determined by ideology. In other words, ideology and devotion to the past-rather than a lack of opportunity or courage-impeded a more profound transformation of the Soviet system in the crucial 1953 to 1964 decade, when a peasantry that could have profited from the disbanding of collective farms still existed. These conditions were absent 30 years later, when there were no peasants that could fuel a Gorbachev NEP, as they were doing for Deng. This difference should be sufficient enough to discount parallels between the two countries in the 1980s without even considering other major differences (e.g., the USSR's multinational and strategic position).

\section{UKRaine AND THE Holodomor: THE NATIONAL AND PEASANT QUESTION IN SOVIET HISTORY}

Intellectuals, spurred by their reaction to the peasants' fate, often contributed to the great season of Soviet reforms: Tatiana Zaslavskaia and Iurii Arutiunian were, for example, shocked by the countryside's appalling poverty while doing research for their doctorates (Zaslavskaya). Already in the early 1950s the village writers (mentioned earlier) were in fact dismantling the official version of collectivization. This "discovery" of rural misery followed different courses, but it was everywhere, Russia included, and was tied to a resurgence of national sentiment-often of the traditional pro-peasant variety. ${ }^{16}$ Ukraine, where as we know the famine taboo was at its strongest, was the significant exception: here language was to serve as a catalyst for national revival.

I believe that this marked differentiation was linked in some manner to the extremely harsh lesson imparted to the Republic in 1930-34. After 1929, urban dwellers throughout the USSR, periodically screened and "cleansed," learned to shut their eyes before what happened in the countryside, which was soon isolated by a wall raised by the Holodomor

\footnotetext{
15 Regarding the situation in China, see Becker, Dikötter, Jisheng, Vogel, and Pantsov. ${ }^{16}$ After the first Russian edition of The Great Soviet Peasant War came out, I received an unexpected letter of support from Igor Shafarevich, who openly linked the destruction of the Russian nation conducted by communism to that of its peasantry.
} 
and the other Soviet famines and then solidified by the new servile system and the legal discriminations (the internal passport first of all) that defined it.

Urban inhabitants-many of whom had relatives in the villages and eyes to see-knew what was happening, but presumably preferred not to, disassociating themselves from a world whose terrible desolation was best left not broached. To many it must have seemed wiser to forget what happened there, under the protection afforded by the relatively generous, albeit in absolute terms miserable, privileges the regime granted to the urban population.

In Ukraine, the stigma was of a double nature: the December 1932 secret provisions on the reversal of Ukrainization (more on this later); the 1933 repression of those who had furthered the Republic's nationalCommunist movement; the policies directed at marginalizing and taming the Ukrainian language and so forth reminded everybody that it was now more "convenient" to be an urban dweller and a Russified one.

It is thus possible to surmise that in Ukraine the wall separating the cities from the countryside grew thicker as a result of a dual process. Firstly, the regime's assault on the villages sent a clear signal to the large Russian and Jewish urban communities, which had often disliked, if not resented, Ukrainization: Things Ukrainian could now be safely discarded, and it was actually advisable to do so. ${ }^{17}$ Secondly, the same signal sounded loudly and clearly to the recently urbanized or newly arrived peasants of Ukrainian stock, who tried, as quickly as possible, to integrate themselves into the revised urban norms in order to escape a fate that must have looked, and, indeed, was terrible.

From 1933 onward full urbanization was also to mean Russification, while Ukrainian was, at most, to be cherished as a folkloric remnant, tainted by its dangerous association with the village and its tragedies. The rediscovery of the Ukrainian language during the late 1950s was therefore, in a way, also an indirect rediscovery of the countryside and of its past, which could not be direct because of the strength of the Holodomor taboo and of the terrible lessons associated with it.

I mentioned the Jewish urban communities in association with the Russian ones. Yet this association is valid only in the case of the few, large cities and for the non-traditional minority of the Jewish world. The processes that devastated the ethnic Ukrainian communities in 1928-33

\footnotetext{
17 Bulgakov's The White Guard provides one of the best depictions of the urban Russians' feelings, but one may find clear signs of similar sentiments in the policies followed by the 1919 Bolshevik Ukrainian government and in the 1925-27 polemics on the application of Ukrainization in the cities.
} 
also badly damaged the majority of the Jewish-Ukrainian ones. Shtetls had been already undermined by the civil war and the great pogroms that accompanied it and were further drained of energy by the great migration of the 1920s to large Soviet Russian cities, something made possible by the abolition of discriminatory tsarist laws. Yet shtetls had largely survived, only to be hit in 1928 by the tightening persecution of their religious leaders and by the arrest and often the deportation of the shopkeepers, traders and merchants, small and medium industrialists, and artisans that marked the end of the NEP and the repression of the nepmeny. Soon afterwards, settlements that thrived upon a mutually beneficial association with Ukrainian villages, albeit somewhat problematic, were ruined by the desolation that de-kulakization, collectivization and, eventually the Holodomor brought upon the latter. The devastation of rural Ukraine thus hit a plurality of the Republic's minority communities, the Mennonite included.

We thus come once more to the crucial problem of the linkage between the peasant and the national question in Soviet history, a linkage essential to understanding its first decades and the role of the Holodomor-and the other famines, the Kazakh first and foremost. ${ }^{18}$ Both Lenin and Stalin understood this linkage very well.

"Land to the peasants" and the nation's "right of self-determination up to separation" were possibly the two most important innovations Lenin introduced in the Marxist vocabulary: the socialist, "worker" revolution in Russia became possible precisely because he created the condition for such a revolution to ride to power by surfing the interrelated peasant and national waves. And these waves were more powerful in places where the land was in "alien" hands, as was often the case in the empire's 'Ukraines,' where Polish, Russian and German lords, or Slavic colonists in Central Asia, controlled large swaths of territory.

Stalin theorized the linkage between the peasant and the national question in his Marxism and the National Question (1913). In fact, the booklet's originality was rooted precisely in the combination of Marxism, "evolutionism" and a Herderism Stalin probably acquired via his previous contacts with the Georgian national movement and through his polemics with Otto Bauer and the Austro-socialist nationality theory. Like Herder, Stalin saw in language the main-albeit not the sole-national marker, and he often reiterated Herder's basic tenet that each and every nationality possesses equal dignity. Stalin also accepted the concept of dominant and

\footnotetext{
18 Both Buttino and Pianciola, for example, have convincingly discussed the peculiar features the peasant/national connection took in "Russian" Turkestan and in Soviet Central Asia, where it was further complicated by religion.
} 
oppressed, or peasant, "peoples," and, like Bauer, supported the idea that the latter were not doomed to be absorbed by the former, as Marx and Engels had maintained in 1848. Rather, Stalin surmised that peasantsposited as per Herder as the true repository of language and thus of the "narod"-could conquer "alien" cities and carry their nations to independence (Graziosi, Vneshniaia i vnutrenniaia politika; van Ree 41-65).

Nationalities, peasants and "peoples," or, more accurately, peasant peoples and peasant nations, thus became the revolution's most important "reserve." Initially, this was true for East Central Europe, but above all it included the European colonies, whose crucial role in the great world transformation of the twentieth century Lenin was perhaps the first to grasp fully. Both Lenin and Stalin thus came to see peasants as a "material" that revolutionaries could manipulate in two ways: as the social explosive needed to unhinge the existing social and political order, and as a nationbuilding substance that had to be defused via industrialization and urbanization in order to deprive nationalism of its main spring and support.

The events of 1917 proved the first diagnosis right. Yet the civil war's experience also taught Bolshevik leaders a different lesson. As Ukraine in 1919 or Western Siberia in 1920 (but also the Northern Caucasus and the Volga regions) indicated, precisely because they were a true revolutionary force, peasants also were extremely dangerous: like all volatile material, they could explode in the face of those trying to handle them. What is more, as in Ukraine during 1919, their upheavals could open the way to external enemies (this being perhaps Stalin's greatest fear in the early 1930s).

Peasants and peasant-nations were thus very useful, but they were also very dangerous. ${ }^{19}$ In 1925, Stalin stated the link he established between the peasant and the national questions in crystal-clear terms:

[T] he national question [is], in essence, a peasant question. Not an agrarian but a peasant question, for these are two different things. It is quite true that the national question must not be identified with the peasant question, for, in addition to peasant questions, the national question includes such questions as national culture, national statehood, etc. But it is also beyond doubt that, after all, the peasant question is the basis, the quintessence, of the national question. That explains the fact that the peasantry constitutes the main army of the national movement, that there is no powerful national movement without the peasant army, nor can there be. That is what is

\footnotetext{
19 The Antonovshchina, which as we know played a crucial role in Lenin's decision to abandon War Communism, fully confirmed the point: as Lenin himself was famously to state at the Tenth Party Congress, "This petty-bourgeois [i.e., peasant] counterrevolution is certainly more dangerous than Denikin, Yudenich and Kolchak combined."
} 
meant when it is said that, in essence, the national question is a peasant question. (Bol'shevik 7, 15 April 1925) ${ }^{20}$

In those very months, Marx's "primitive accumulation" theory, which Evgenii Preobrazhenskii and the Left applied to the Soviet case, helped Stalin formulate a view that turned the countryside into the internal colonies that were to provide the means needed to solve the Soviet economic crisis and build socialism speedily. However, this required unleashing a full-scale attack against peasants and peasant-nations that had just proved their dangerousness. A new, harsh monarch, capable of winning this war, was thus needed. As Bukharin explained to Kamenev:

\begin{abstract}
“Stalin's line (as expressed at the Plenum) is such: 1. Capitalism developed at the expense of the colonies, through loans, or through exploitation of workers. We don't have any colonies, they don't give us any loans, hence our basic resource is the tribute from the peasantry (You understand that this is the same as Preobrazhenskii's theory); 2. The more socialism grows, the more resistance it will encounter (see the phrase in the resolution)... This is idiotic illiteracy; 3 . When tributes are required and resistance grows, you need strong leadership... Stalin reasons so: "I provided grain through extraordinary measures... If such measures are needed, I am the only one capable of enforcing them"... What is to be done? What do you do, when you deal with such an enemy: Genghis Khan - the low culture of the Central Committee... Stalin's policies are leading to a civil war. He will have to drown revolts in blood." (Fel'shtinskii 182-203; Graziosi, Sovetskii soiuz)
\end{abstract}

Being a war against the peasantry, the assault Stalin was unleashing also was, according to his very theory, a war against peoples and nations in which the state could attempt to mold the countryside's "ethnographic material" 21 by resorting to repression, hunger, and language-cultural policies.

As for Stalin himself, and thus also Stalinism, the previously mentioned strengthening of his personal dictatorship in 1929 was solidified and intensified by the "victory" over the peasants and peasant nations, Ukraine first of all. Fear, the fear of Stalin that dominated the country from his closest collaborators to the lowliest kolkhoznik after 1932-33 played a crucial role in this process. What other feeling could one have for a man who, in order to save his power and solve the crisis the regime had fallen

\footnotetext{
20 Stalin added that without an understanding of this link, it would be impossible to grasp the profoundly popular and profoundly revolutionary character of the national movement.

21 These are the words of a high-ranking OGPU official working in Ukraine in 1933 (Graziosi, Lettere da Kharkov 168).
} 
into as a consequence of his policies, had not hesitated to let millions die of hunger? The quality and the scale of this action went far beyond even the extremely low moral standard of Bolshevik leaders who readily shot tens of thousands of "enemies" during the first year of collectivization, but who were now overwhelmed-as the minutes of the Seventeenth Congress of the AUCP(B) in early 1934 reveal to those who read them attentively-by a catastrophe in which some saw the signs of their own impending doom.

Fear thus became a key building block of Stalin's cult. His internalization as a cruel father with overwhelming power took a decisive step forward as a consequence of the cruel and massive use of hunger to "teach a lesson." After 1933, Stalin was no longer just a supreme leader. He became the father-owner (padre-padrone, as one would say in Italian) holding the power of life and death over his subjects and the capability of exercising it without hesitation on an unprecedented scale, holding in his hands the fate of single individuals as well as of entire nationalities and social groups.

As Boris Pasternak so well understood (Pasternak 659), the famine marked a qualitative change in the lie that had grown with the Soviet regime since its inception, but with even greater speed after 1928. To suggest a brilliant future, in which somebody could still believe, in the face of a grim reality-as Gorky did with socialist realism-was very different from proclaiming that life had already become more joyful (even in the face of heaps of corpses) while asking to be thanked for it.

Those heaps of corpses of direct, innocent victims of state policy bring us to one of the most fundamental questions raised in Soviet history by the Holodomor and the other famines of 1931-33, not to mention other events such as the national deportations of 1943-44 that killed in a few months up to 20-25 percent of the "punished peoples," or the almost complete physical liquidation of the Orthodox Church in the 1930s. The question I am alluding to is, of course, genocide. Norman Naimark has recently and correctly reminded us of its crucial importance (Naimark; Kramer), stressing Stalin's personal role in Soviet genocides to which only his death put a sudden stop. A few years ago, in a personal letter to this writer, Oleg Khlevniuk had pointed out that Stalin's mind usually worked along "genocidal" lines: "No matter what problem arose in the country, it was solved through the application of violence directed at specific and well-defined socio-cultural or national groups of the population." These groups, and their treatment, varied over time according to the internal and international situation, the despot's own beliefs, and the evolution of his paranoia, and thus of his cruelty.

In the case of the Holodomor, the trigger was Stalin's previously discussed combination of the social, i.e., the peasant, and the national 
factors. These pushed him in late fall 1932 to escalate what would have in due course become, by the spring of 1933, a serious but limited famine, caused by his own policies, into a Holodomor intended not to destroy, but to emasculate the Ukrainian nation by breaking its peasantry and crippling its intellectual and political elite. ${ }^{22}$ Once this is understood, the polemics between the "peasant" and the "national" interpretation of the famine lose their raison d'être. Not surprisingly, as Terry Martin proved (Martin 273308), Stalin was the first to give the famine a "national interpretation." Revealingly, the already mentioned secret 1932 decrees that reversed indigenization policies in Ukraine and in the Kuban, were named "On Grain Procurements in Ukraine, the Northern Caucasus and the Western Oblast."23 The decrees noted that those policies had not only failed to disarm nationalistic feelings in Ukraine, but had even helped them grow, i.e., producing enemies with a Party card in their pocket. Peasants, therefore, were not the sole culprits of the crisis, but shared responsibility with the Ukrainian cultural elites and the national-Communist leadership. ${ }^{24}$

Ukrainization programs in the Russian republic were subsequently abolished, and several million Ukrainians living in the RSFSR lost the education, press, and self-government rights that other nationalities continued to enjoy. More importantly, an aggressive attack on the Ukrainian language was launched in Ukraine as well, contributing to the already mentioned re-Russification of the Ukrainian cities. Ukrainian again was to become a second-rate, subordinated language that people, intending to progress in life, had to abandon. Moreover, special policies were adopted to bring it normatively closer to Russian and to repress the thousands of cadres that had promoted it in previous years (Yefimenko 69-98). The Ukrainian peasants and intelligentsia, the Ukrainian language and culture were thus subjected in 1932-34 to policies that, taken together, fully fit the "genocide" category adopted by the United Nations.

This brings us for the last time to the role the Holodomor and the other famines of the early 1930s should play in attempts to assess the viability of the Soviet system and to understand the collapse of the USSR. What can it mean for a state and a regime to have a genocide (and in the Soviet case, possibly, more than one) lurking in its own past, and for a "system"because the Soviet Union was indeed a particular social and economic system-to have been born out of a genocidal confrontation with the

22 I elaborate on this point in Soviet 1931-33 Famines and in my forthcoming "The Uses of Hunger."

${ }^{23}$ For the text in English translation, see Klid and Motyl 245-47.

24 In this and in the following paragraph, I follow my contribution "Stalin's Genocides, and...?" 
majority of its own population? More specifically, what consequences may have derived from concealing such a past under a heap of good words about that very system and its intentions, good words in which that very regime's elites at a certain point started to believe? What consequences did such a startling development of untruth have on Soviet history?

In such conditions, the understanding, but also the simple intuition of the truth, and its assertion, even-and perhaps especially-by former believers may have an explosive impact, both at the personal and the social level. In fact it did, and more than once, in Soviet history. The problem thus became how to avoid the resurfacing of truth. But the growing ignorance of the past increasingly weakened the effort to control it. Above all, by their sheer "dimensions," the 1931-33 famines made it almost impossible to resolve the contradiction between official discourse and truth, thus laying the foundation for their recurrent exposition.

In this light, the Holodomor assumes the features of a formidable obstacle to the ability to reform a system that could not speak the truth about its own past and that was swept away when it came to light. Ironically, people who deemed the system's evolution possible and wanted to promote it further by settling accounts with that past often set this process in motion. What they discovered was that the legacy of the past could not be brought under their control, and its public exposure undermined the very legitimacy of the system they sincerely wished to amend.

\section{CONCLUSIONS}

I wish to conclude by examining the impact that the awareness of the Holodomor and the reality of rural life in the USSR in the 1930s may-or should-have on the image of the Soviet Union during that decade and therefore also on the various images produced over time by students and observers of the Soviet system.

Soviet historians in the West have often been divided into two opposing groups, the so-called totalitarian school and the anti-totalitarian (revisionist) one, which included the social historians of the 1970s and 1980s. It is my impression that the Holodomor, the Kazakh famine, the brutality of de-kulakization and collectivization, the unquestionable mass peasant opposition to the regime (with peasants, including nomads, making up nearly 80 percent of the Soviet population), and the chaos, suffering, and misery that dominated rural life for years, belie any interpretations of Stalin's USSR as a modern system that had the support of a substantial part of the population whose conscience it successfully manipulated. 
What we have learned since 1991 about the repressions of 1937-38-a series of pre-emptive, mass cleansing operations rather than a random resort to terror in order to "atomize" the population-also seems to confirm the need for a new image of the USSR in the 1930s. Those very "mass operations" also confirm the weak legitimacy as well as the profound unpopularity of a regime that in peace-time deemed necessary to execute in 16 months some 700,000 internal enemies, a rather unique case in history.

In fact, the Stalinist regime resembles much more an "evil empire" built upon the oppression of villages and peoples (but also of workers and intellectuals) than a modern "totalitarianism" capable of controlling and mobilizing its "citizens." This does not deny that the Stalinist system also had, and built, its own supporting groups and strata as well as the obvious fact that there also was a Soviet "modernization," with its accompanying urbanization, industrialization, and the like which indeed ended up producing a Soviet "modernity."

Yet, both the totalitarian and the revisionist schools may have given too much credit to a Soviet "modernity," even though from radically divergent approaches. In the 1930s Soviet modernity was still little more than a project whose realization went hand-in-hand with the reproduction of elements and institutions that can only be defined in terms of a "return to a (non-existent) past": agrarian servitude, mass famines, cannibalism, primitive varieties of forced labour, the destruction of trade unions and of social welfare provisions, systematic torture, witch hunts, and the like.

Even later, Soviet modernity was a system in which status and personal connections (sviazy) were more important than money, as was typical of traditional societies. Moreover, it was dominated by an extremely statist, isolationist, and authoritarian regime, in which political power was thoroughly intertwined with an official, para-religious ideology. Resorting to an oxymoron, the postwar USSR could thus be termed a "modern" ancien régime, and in the long run it also could not survive because of this contradictory nature. For this very reason, I deem it untenable to analyze the course of its life just in terms of "modernization."25

There has been after the Second World War, and especially after 1953, a Soviet modernity, and one may perhaps speak of a Soviet "totalitarianism" of the Brezhnev years, a totalitarianism built upon a cocktail of control, modernity, fear, welfare, and victory-related legitimacy, but definitely not the mass violence and repression of the Stalin era.

\footnotetext{
25 More on the question of Soviet "modernity" and on the debate between the "modernist" and the "neo-traditionalist" interpretation of the Soviet experiment can be found in Qu'est-ce que l'Union soviétique? Intérpretations, historiographies, mythologies (Graziosi, Histoire de l'URSS 359-84).
} 
Before 1941, however, the clash between the state, the peasantry and the nationalities - and we know how much and how closely these two "questions" were related, and not only in Stalin's mind-occupied centre stage. It seems to me that both the totalitarian and the anti-totalitarian schools missed this crucial point, and thus in a way fell victim to the taboo on peasants and nationalities that Stalin built around Soviet history, a taboo of which the Holodomor was for decades the lynchpin.

\section{Works Cited}

Becker, Jasper. Hungry Ghosts: Mao's Secret Famine. New York: The Free Press, 1996. Print.

Beznin, Mikhail and Tat'iana Dimoni. "Povinnosti rossiiskikh kolkhoznikov v 19301960-e gody." Otechestvennaia istoriia 2 (2002): 96-111. Print.

Beznin, Mikhail, Tat'iana Dimoni, and Larisa Iziumova. Povinnosti rossiiskogo krest'ianstva v 1930-1960-kh godakh. Vologda: Vologodskii NKTS TSĖMI RAN, 2001. Print.

Buttino, Marko. Revoliutsiia naoborot. Sredniaia Aziia mezhdu padeniem tsarskoi imperii i obrazovaniem SSSR. Moscow: Zven'ia, 2007. Print.

Chernyaev, Anatoly. My Six Years with Gorbachev. University Park: Pennsylvania State University Press, 2000. Print.

Colton, Timothy. Yeltsin: A Life. New York: Basic Books, 2008. Print.

Danilov, Viktor, Roberta Manning, and Lynne Viola, eds. Tragediia sovetskoi derevni: Kollektivizatsiia $i$ raskulachivanie: Dokumenty i materialy $v 5$ tomakh, 19271939. 5 vols. Moscow: Rosspen, 1999-2006. Print.

Devis, Robert and Oleg Khlevniuk. "Otmena kartochnoi sistemy v SSSR. 1934-1935 gody." Otechestvennaia istoriia 5 (1999): 87-108. Print.

Dikötter, Frank. Mao's Great Famine: The History of China's Most Devastating Catastrophe, 1958-1962. New York: Walker \& Co., 2010. Print.

Fel'shtinskii, Iurii. "Dva epizoda iz istorii vnutripartiinnoi bor'by: konfidenstial'nye besedy Bukharina." Voprosy istorii 2-3 (1991): 182-203. Print.

Fitzpatrick, Sheila. Stalin's Peasants: Resistance and Survival in the Russian Village After Collectivization. New York: Oxford University Press, 1994. Print.

Gorbachev, Mikhail. Memoirs. New York: Doubleday, 1996. Print.

---. Naedine s soboi. Moscow: Grin Strit, 2012. Print.

Graziosi, Andrea. The Great Soviet Peasant War. Bolsheviks and Peasants, 1918-1934. Cambridge, MA: Harvard Ukrainian Research Institute, 1996. Print.

---. Histoire de l'URSS. Paris: PUF, 2010. Print.

---. "The Great Famine of 1932-33: Consequences and Implications." Harvard Ukrainian Studies 25.3-4 (2001): 157-166. Print.

---. L'Urss dal trionfo al degrado. Storia dell'Unione sovietica, 1945-1991. Bologna: Il Mulino, 2008. Print.

---. L'Urss di Lenin e Stalin. Storia dell'Unione sovietica, 1914-1945. Bologna: Il Mulino, 2007. Print.

---. Lettere da Kharkov. Turin: Einaudi, 1991. Print. 
---. Sovetskii soiuz v 209 tsitatakh, 1914-1991. Moscow: Rosspen, 2010. Print.

---. "The Soviet 1931-33 Famines and the Ukrainian Holodomor: Is a New Interpretation Possible, What Would Its Consequences Be?" Hunger by Design: The Great Ukrainian Famine and Its Soviet Context. Ed. Halyna Hryn. Cambridge, MA: Harvard University Press, 2009. 1-19. Print.

---. "Stalin, krest'ianstvo i gosudarstvennyi socializm: evoliutsiia vzaimootnoshenii, 1927-1951 gg." Istoriia Stalinizma: krest'iastvo i vlast'. Moscow: Rosspen, 2011. 12-32. Print.

---. "Stalin's Genocides, and...?", Forum: Reappraising Mass Terror, Repression, and Responsibility in Stalin's Regime, Perspectives on Norman Naimark's Stalin's Genocides. Journal of Cold War Studies 14.3 (2012): 155-69. Print.

---. "The Uses of Hunger: Stalin's Solution and the Peasant and National Questions in Soviet Ukraine, 1932-1933." Famines in European Economic History: The Last Great European Famines Reconsidered. Ed. D. Curran, L. Luciuk and A. Newby. London and New-York: Routledge, forthcoming. Print.

---. "Vneshniaia i vnutrennaia politika Stalina: o natsional'nom voprose v imperskom kontekste, 1901-1926 gg." Istoriia Stalinizma: itogi i problemy izucheniia. Ed. Joerg Baberowski et al. Moscow: Rosspen, 2011. 215-35. Print.

Hessler, Julie. A Social History of Soviet Trade: Trade Policy, Retail Practices, and Consumption, 1917-1953. Princeton: Princeton University Press, 2004. Print.

Inkeles, Alex and Raymond A. Bauer, The Soviet Citizen: Daily Life in a Totalitarian Society. Cambridge, MA: Harvard University Press, 1959. Print.

"Iz ob"iasnitel'noi zapiski v sel'skokhoziaistvennyi otdel TsK VKP(b) o priusadebnykh uchastkakh kolkhoznikov Sverdlovskoi oblasti, mai 1939 g." Kolkhoznaia zhizn' na Urale. Ed. Jan Kessler and G. Kornilov. 111-15. Print.

Jisheng, Yang. Tombstone. The Great Chinese Famine, 1958-1962. New York: Farrar, Straus and Giroux, 2012. Print.

Kessler, Jan and G. Kornilov, eds. Kolkhoznaia zhizn' na Urale, 1935-1953. Moscow: Rosspen, 2006. Print.

Khlevniuk, Oleg et al., eds. Pis'ma I.V. Stalina V.M. Molotovu 1925-1936 gg. Moscow: Rossiia Molodaia, 1995. Print.

Khlevniuk, Oleg and Yoram Gorlizki. Cold Peace: Stalin and the Soviet Ruling Circle, 1945-53. Oxford: Oxford Unversity Press, 2004. Print.

Khrushchev, Nikita. Memoirs of Nikita Khrushchev, vol 2: Reformer [1945-1964]. Ed. Sergei Khrushchev. University Park, PA: Pennsylvania State University, 2006. Print.

Klid, Bohdan and Alexander J. Motyl, eds. The Holodomor Reader: A Sourcebook on the Famine of 1932-1933 in Ukraine. Edmonton and Toronto: Canadian Institute of Ukrainian Studies Press, 2012. Print.

Kozlov, Vladimir. Massovye besporiadki v SSSR pri Khrushcheve i Brezhneve, 1953nachalo 1980-kh gg. Novosibirsk: Sibirskii khronograf, 1999. Print.

Kramer, Mark, ed. "Perspectives on Norman Naimark's Stalin's Genocides." Journal of Cold War Studies 14.3 (2012): 149-89. Print.

Krasil'nikov, Sergei and Aleksandr Shadt, eds., Marginaly $v$ sovetskom sotsiume, 1930-e - seredina 1950-kh gg. Novosibirsk: RAN NGU, 2010. Print.

Krasil'nikov, Sergei. "Repressivnoe raskrest'ianivanie v 1930-e gody." Istoriia Stalinizma: krest'ianstvo i vlast'. Moscow: Rosspen, 2011. 45-55. Print. 
Kul'chyts'ky, Stanislav. "Il tema della carestia nella vita politica e sociale dell'Ucraina alla fine degli anni Ottanta." La morte della terra. La grande carestia in Ucraina nel 1932-33. Ed. G. De Rosa and F. Lomastro. Rome: Viella, 2004. 431-49. Print.

Lewin, Moshe. The Making of the Soviet System: Essays in the Social History of Interwar Russia. New York: The New Press, 1985. Print.

Lih, Lars T., Oleg V. Naumov, and Oleg T. Khlevniuk. Stalin's Letters to Molotov, 19251936. New Haven and London: Yale University Press, 1995. Print.

Livshin, A.I and I.B. Orlov, eds. Sovetskaia povsednevnost' i massovoe soznanie. 19391945. Moscow: Rosspen, 2003. Print.

Maksudov, Sergei. "Dehumanization: The Change in the Moral and Ethical Consciousness of Soviet Citizens as a Result of Collectivization and Famine." After the Holodomor: The Enduring Impact of the Great Famine on Ukraine. Ed. Andrea Graziosi, Lubomyr Hajda and Halyna Hryn. Cambridge, MA: Harvard Ukrainian Research Institute, 2013. 123-48. Print.

Martin, Terry. The Affirmative Action Empire: Nations and Nationalism in the Soviet Union, 1923-1939. Ithaca, NY: Cornell University Press, 2001. Print.

Meslé, France and Jacques Vallin, Mortalité et causes de décès en Ukraine aux XXe siècle. Paris: Institut national d'études démographiques, 2003. Print.

Naimark, Norman. Stalin's Genocides. Princeton, N.J.: Princeton University Press, 2010. Print.

Pantsov, Alexander. Mao: The Real Story. New York: Simon \& Schuster, 2012. Print.

Pasternak, Boris. Il dottor Živago. Milano: Feltrinelli, 1957. Print.

Pianciola, Nicola. Stalinismo di frontiera. Colonizzazione agricola, sterminio dei nomadi e costruzione statale in Asia centrale (1905-1936). Roma: Viella, 2009. Print.

"Pis'mo iz kolkhoza "1-e Maia" Uinskogo raiona Sverdlovskoi oblasti, 18 ianvaria 1938 g." Kolkhoznaia zhizn' na Urale, 1935-1953. Ed. Jan Kessler and G. Kornilov. Moscow: Rosspen, 2006. 134-41. Print.

Polian, Pavel. Ne po svoei vole: istoriia i geografiia prinuditel'nykh migratsii $v$ SSSR. Moscow: Memorial, 2001. Print.

Popov, Vasilii, ed. Rossiiskaia derevnia posle voiny, 1945-1953, Moscow: Prometei, 1993. Print.

Sasse, Gwendolyn. The Crimea Question: Identity, Transition, and Conflict. Cambridge, MA: Harvard Ukrainian Research Institute, 2007. Print.

Shapoval, Iurii. “The Ukrainian Years, 1894-1949.” Nikita Khrushchev. Ed. William Taubman, Sergei Khrushchev, and Abbott Gleason. New Haven: Yale University Press, 2000. 8-43. Print.

Stalin, Iosif. "Iz rechi v komissii 2-go Vsesoiuznogo s"ezda kolkhoznikov udarnikov." Pravda, 15 March 1935. Print.

Stalin, Iosif. Ekonomicheskie problemy sotsializma v SSSR. Moscow: Gos. Izd-vo polit. lit-ry, 1952. Print.

Sysyn, Frank. "The Ukrainian Famine of 1932-33": The Role of the Ukrainian Diaspora in Research and Public Discussion." Studies in Comparative Genocides. Ed. Levon Chorbajian and and George Shirinian. New York: St. Martin's Press, 1999. 182-215. Print.

van Ree, Erik. The Political Thought of Joseph Stalin: A Study in Twentieth-Century Revolutionary Patriotism. London: Routledge, 2002. Print. 
---. "Heroes and Merchants: Stalin's Understanding of National Character." Kritika: Explorations in Russian and Eurasian History 1 (2007): 41-65. Print.

Vogel, Ezra. Deng Xiaoping and the Transformation of China. Cambridge, MA: Harvard University Press, 2011. Print.

Werth, Nicholas and Alex Berelowitch, eds. L'Etat soviétique contre les paysans. Rapports secrets de la police politique. Paris: Tallandier, 2011. Print.

Yefimenko, Hennadii. "The Kremlin's Nationality Policy in Ukraine after the Holodomor of 1932-33." After the Holodomor: The Enduring Impact of the Great Famine on Ukraine. Ed. Andrea Graziosi et al. Cambridge, MA: Harvard Ukrainian Research Institute, 2014. 69-98. Print.

Yeltsin, Boris. Against the Grain: An Autobiography. New York: Summit Books, 1990. Print.

Zaslavskaya, Tatyana. The Second Socialist Revolution. London: Tauris, 1990. Print.

Zima, Veniamin. Golod v SSSR. 1946-1947 godov: proiskhodzhenie i posledstviia. Moscow: IRI RAN, 1996. Print.

Zubkova, Elena. Poslevoennoe sovetskoe obshchestvo. Politika i povsednevnost', 19451953. Moscow: Rosspen, 2000. Print.

Zubkova, Elena and T. Iu. Zhukova, eds. Na "kraiu" sovestkogo obshchestva. Sotsial'nye marginaly kak ob"ekt gosudarstvennoi politiki, 1945-1960-e gg. Moscow: Rosspen, 2010. Print. 
(C) 2015 East/West: Journal of Ukrainian Studies (ewjus.com) Volume II, No. 1 (2015) 